DOI :10.31357/fapsmst.2006.00483

\title{
KNOWLEDGE ATTITUDE \& BEHAVIORS OF THE FISH STAKE-HOLDERSIN FISH CHAIN ON FISH
}

애

T.K.S.NIKamumarathne

M.Sc 


\section{KNOWLEDGE ATTITUDE \& BEHAVIORS OF THE FISH STAKE-HOLDERSIN FISH CHAIN ON FISH}

By

Tele Korala Sinesha Nuwan Karunarathne

A thesis submitted in partial fulfillment of the requirement of the degree of

Master Science

In

Food Science and Technology

Of the Department of Food Science and Technology University of Sri Jayawardanapura

Sri Lanka

Year 2006 
I prof Atthur Bamunuarachchi here by certify that the statement in the proceeding pages made by candidate is true and that this is suitable for submission for the university for the purpose of evaluation.

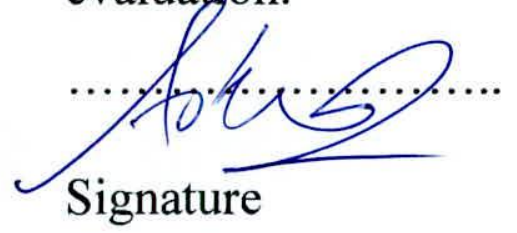

Supervisor

Prof Atthur Bamunuarachchi

Department of Food Science and Technology

University of Sri Jayawardanapura

Gangodawila, Nugegoda, Sri Lanka

I Dr. K.K.D.S. Ranawera here by certify that the statement in the proceeding pages made by candidate is true and that this is suitable for submission for the university for the purpose of evaluation.

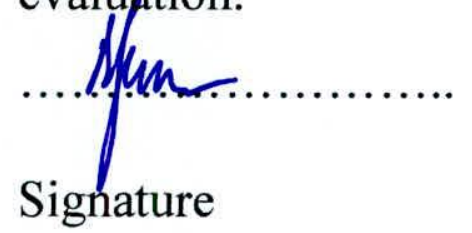

Supervisor

Dr. K.K.D.S. Ranawera

Department of Food Science and Technology

University of Sri Jayawardanapura

Gangodawila, Nugegoda, Sri Lanka 


\section{Declaration}

The work in this thesis was carried out under the supervision of Prof Atthur Bamunuarachchi and Dr. K.K.D.S. Ranawera (Food science and Technology Department, University of Sri Jayawardanapura) and report on a thesis has not been submitted to any university for another degree and has not been presented or accepted in any previous application for a degree.

S Bamanathre......

Signature

T.K.S.N.Karunarathne 


\begin{abstract}
Fisheries are a key sector in Sri Lanka's national economy. Specially marine fisheries has significant role having $90 \%$ contribution to the fish production. The actual fish production in 2004 was 253190 MT. Deterioration of the quality of fish during catch, handling, transportation, loading, unloading, and marketing is over $40 \%$ of the catch. This is related to lack of knowledge, behaviors and attitude of the fishermen, fish handlers, transporters and fish vendors. Therefore this study was carried out to knowledge, attitude and behaviors of stakeholders in the fish chain on fish. This study was conducted among the fishing community in Matara district.

The objectives of this study were to determine knowledge, attitude and behaviors of fish stakeholders on fish and how to implement the quality deterioration of fish. In this study random sampling method was used to select 90 fisher people in Matara district including fishermen, boat owners, crew members, fish transporters and fish vendors. The data were gathered by using interview schedule method, observation and group discussion.
\end{abstract}

The collected data used to explain the knowledge, attitude and behaviors of the fish stakeholders on fish. The result showed that $71 \%$ of participant in illiteracy and only 2 $\%$ have biological and technical knowledge about fishing and fish handling. Only $10 \%$ of participants know method of icing and ratio of icing. According to observation and discussion, root attitude and behaviors about fish handling and storage affect the quality deterioration of fish.

Implementation of adequate fisheries management process and awareness programme for fishing, fish handling and storage is timely need for change attitudinal and behavioral to ensure sustainable fisheries and continued livelihood for today's as well as tomorrow fishermen. 


\section{Acknowledgment}

First I would like to thank prof. Athar Bamunuarachchi, Coordinator of the MSc Food Science and Technology Programme of Sri Jayawardanapura University and Dr. K.K.D.S. Ranawera, Head of the Department Food Science and Technology, Who are my supervisors in this projects for their permission, support and for the guidance and valuable advice given to me to do my project.

I take this opportunity to express my sincere gratitude to Mr.G. Piyasena, Director General of Department of Fisheries and Aquatic Resources of Sri Lanka and other Officers of department for their help to do this project. And also I specially thank Mr. V.G.J. Shelton, Assistant Director of Department of Fisheries and Aquatic Resources, District office Matara and all Fisheries Inspectors and Fishery Resources Management Assistants in Matara District for their help to collect information from fish stakeholders and conducting awareness Programmes.

I would like to acknowledge Mr. Mahinda Gunarathna, District officer of United Nation Food and Agriculture Organization, district office Matara and other officers for enabling me to carry out the project work and also providing information. I am also grateful to Mr. Nirosh Happuarachchi, Livelihood Officer of International Organization for Migration for his help to get Photographs.

My appreciation goes to Librarian of University of Ruhuna and non-staff members and also I am grateful to laboratory staff and others who helped me in the University of Ruhuna for their support.

I am also grateful to the Academic staff and Non academic staff members of Department Food Science and Technology of Sri Jayawardanapura University and other departments for their support.

My gratitude is also in extended to others who helped me to sharpen my knowledge and skills to do this project.

Finally I would like to note my heart felt thanks to my parents and my brother and Punvidu Jayasinghe for sharing all my depressions and successes and for their voluble support. 


\section{Table of contents}

$\begin{array}{lr}\text { Abstract } & \text { i } \\ \text { Acknowledgment } & \text { ii } \\ \text { Table of contents } & \text { iii } \\ \text { List of Tables } & \text { v } \\ \text { List of Figures } & \text { vi }\end{array}$

$\begin{array}{ll}\text { 1. Introduction } & 1\end{array}$

2. Literature review 4

$\begin{array}{ll}\text { 2.1 Marine fish } & 4\end{array}$

2.2 Composition \& Nutrition 4

2.3 Spoilage of fish 5

$\begin{array}{ll}2.4 \text { Marine sector } & 6\end{array}$

$\begin{array}{ll}2.5 \text { History of Fishery industry in Sri Lanka } & 7\end{array}$

2.6 Fishing Methods

2.7 Technical characteristics of coastal fishing crafts in Sri Lanka 21

2.8 Fishing vessels in Sri Lanka $\quad 22$

$\begin{array}{lr}\text { 3. Methodology } & 27\end{array}$

$\begin{array}{ll}3.1 \text { Selection of study area } & 27\end{array}$

$\begin{array}{lr}3.2 \text { Sampling procedure } & 27\end{array}$

$\begin{array}{ll}\text { 3.3 Data collection methods } & 28\end{array}$

$\begin{array}{ll}3.4 \text { Experimental analysis } & 31\end{array}$ 
$\begin{array}{ll}3.6 \text { Limitations } & 33\end{array}$

4. Results and Discussion $\quad 34$

$\begin{array}{ll}4.1 \text { Age } & 34\end{array}$

4.2 Literacy \& Educational level of the fishing community 34

$\begin{array}{ll}4.3 \text { Experience } & 36\end{array}$

$\begin{array}{ll}4.4 \text { Fishing location } & 38\end{array}$

$\begin{array}{ll}4.5 \text { Type of fishing vessels } & 38\end{array}$

$\begin{array}{ll}\text { 4.6 Fish handling } & 40\end{array}$

$\begin{array}{ll}4.7 \text { Fish transporting } & 43\end{array}$

$\begin{array}{ll}4.8 \text { Income distribution } & 45\end{array}$

$\begin{array}{ll}4.9 \text { Fish marketing } & 47\end{array}$

4.10 Tri Methyl Amine content of Fish $\quad 48$

4.11 Community strengthen Programme $\quad 49$

$\begin{array}{lr}4.12 \text { Discussion } & 50\end{array}$

$\begin{array}{lc}\text { 5.0 Conclusions and Recommendations } & 65\end{array}$

$\begin{array}{ll}5.1 \text { Conclusions } & 65\end{array}$

$\begin{array}{lc}5.2 \text { Recommendations } & 66\end{array}$

\section{References}

Appendix 1

Appendix 2

Appendix 3

Appendix 4 


\section{List of Table}

2.1 Technical characteristics of coastal fishing craft in Sri Lanka

4.1 Education level among fishing communities and other communities

In Matara district

4.2 Details of cost of production and income of 3 production system in Dondra

4.3 Details of cost of production and income of 3 production system in Mirissa

4.4 TMA content of different time

4.5 TMA content of fish in ice 


\section{List of Figures}

$\begin{array}{lr}\text { 2.1 Coastal fish production trend from } 1957-2000 & 8\end{array}$

$\begin{array}{ll}\text { 2.2 Factors influencing freshness of fish } & 27\end{array}$

3.1 Sample frame
29

4.1 Age Distribution of the fishing Community 34

4.2 Literacy of boat owners and crew people 35

$\begin{array}{ll}\text { 4.3 Literacy of fish vendors } & 35\end{array}$

4.4 Literacy of fish transporters $\quad 35$

4.5 Literacy of sample population $\quad 35$

4.6 Experience about fishing related activity 36

$\begin{array}{ll}\text { 4.7 Following fish related activity } & 37\end{array}$

$\begin{array}{ll}4.8 \text { Reasons for enter fishing related activity } & 37\end{array}$

$\begin{array}{ll}4.9 & \text { Fishing Location } \\ & 38\end{array}$

4.10 Type of Vessels

$\begin{array}{ll}4.11 \text { Traditional Canoe } & 39\end{array}$

$\begin{array}{ll}4.12 \text { FRP boat } & 39\end{array}$

4.13 Ton $3 \frac{1}{2}$ One day boat

4.14 Multi day boat $\quad 39$

$\begin{array}{ll}4.15 \text { Icing fish } & 40\end{array}$

4.16 Knowledge about ice and fish ratio $\quad 40$

4.17 Fish on boat in FRP $\quad 40$

4.18 Unloading one by one $\quad 41$

4.19 Dock side weighing 41 
4.21 Weigh fish in landing site $\quad 41$

4.22 Fish display on dock $\quad 42$

$\begin{array}{ll}4.23 \text { Gathering squid } & 42\end{array}$

4.24 Fish display on dock $\quad 42$

4.25 Unloading on FRP 43

4.26 Rinse water 43

4.27 Fish weigh in dock 43

4.28 Fish unloading and washing 43

4.29 Fish packed in insulated truck 43

4.30 Fish transporting vehicle 44

4.31 Use of ice $\quad 44$

4.32 Use of packing material 44

$\begin{array}{ll}4.33 \text { Fish Market } & 47\end{array}$

$\begin{array}{ll}4.34 \text { Fish retailer } & 47\end{array}$

4.35 Unscientific and Ill managed fish stole $\quad 47$

$\begin{array}{ll}4.36 \text { Unhygienic practices close fish stole } & 47\end{array}$

4.37 Workshop introduce long line technology 49

4.38 Awareness programme in Fish handling $\quad 49$ 


\section{INTRODUCTION}

Sri Lanka is an island state in the Indian Ocean, south-east of the Indian sub-continent between latitudes $6-10^{\circ} \mathrm{N}$ longitudes $80-82^{\circ} \mathrm{E}$. The island is approximately 66,000 $\mathrm{km}^{2}$ with a $1340 \mathrm{~km}$ long coastline. Sri Lanka claims sovereign rights of $223,000 \mathrm{~km}^{2}$ of Exclusive Economic Zone (EEZ) of the Indian Ocean.

In Sri Lanka fisheries play in important role for the economy by providing employment, food security and foreign exchange earnings. In 2004 the fisheries sector contributed nearly two percent to gross domestic product and employed over 300000 persons directly and in related activities. The fishing industry became an important foreign exchange earner for the country. The marine fish production in Sri Lanka was estimated at 253,190 MT in 2004 , which is about $88 \%$ of the total fish production in the country.

Fish and fish products, being highly spoilable, deserve special care and attention being paid to them from the catching point to the frying-pen. The living habitats of fish are completely different from its post-harvest environments and its quality depends on many factors, such as intrinsic composition, degree of spoilage, damage, deterioration during harvesting, cleaning, washing, handling, preservation, processing, storage, transportation, distribution and marketing

Socio-cultural aspect of the fishing community is that, there is a greater ancestral relationship between fishing and fishers. Generational link (relationship of fishing as an occupation pass down from father to son) was reported to be $75 \%$ of 83,776 active fishers in 1996. There are three reasons for this high generational link. These are Low level of education, rare alternative employment opportunities and relatively higher 
income with independence. As far as education level of fishers is concerned, $80 \%$ of the active fishers have attended only primary schools.

Active fishers use 31,663 boats and the diverse types of traditional and large scale fishing craft in 2004 , owned and operated by private individuals. In coastal fishery use multi gear fishing gears as beach seine, hand line and gillnet targeting a large number of species and offshore fishing use large mesh drift gill net fishery and long line fishery. Most traditional fishermen landed their fish catch at the estimated 700 landing sites on beaches and estuaries and river mouths in Sri Lanka. Larger boats tied up at anchorages used small boats to land their catch. The multi day boats generally and some of the day boats used the 12 fishery harbours.

Fish landed at fishery harbours, anchorages and fish landing sites is either transported to major urban centers such as Colombo, Kandy, Galle etc or sold locally. Fish retailing is done through larger urban fish markets, private sector owned fish stalls and fish retailing outlets or vendors using motorcycle and cycle. Fish transportation is done in insulated or non-insulated covered transport vehicles, packed in wooden or plastic boxes with ice.

Post harvest losses are major issues in offshore fisheries as well as coastal fishery. Over $40 \%$ of the catch is reported to be landed in poor quality. This is related to fishing method, storage on deck, improper handling, inadequate and low quality ice, untimely icing, improper loading and unloading practices and improper transport method. In adequate infrastructure facilities as well as knowledge, attitude and behavior of the fishing community gradually affect poor quality fish. Inadequate fisheries management overrides many of the issues discussed above. All operations are carried out in such a way that minimizes the cost factor. 
Contribution of the fish production to total food production is $2 \%$ but $70 \%$ of the Sri Lankan people animal protein requirement full fill by the fish foods. In 1996 per capita fish consumption in Sri Lanka is $13 \mathrm{~kg}$ and it come to $16 \mathrm{~kg}$ at 2000 but according to medical decision it should become $21 \mathrm{~kg}$ per year. Therefore enhancing the production of fished, quality of fish and productivity of fishing community and fishing industry as well as improving the socio economic conditions of the fishing community are very important.

Matara district situated in coastal belt therefore fishing industry became an important livelihood in this district coastal community. According to Department of Fisheries data Matara district second only Jaffna district annual fish production in 2004.

\subsection{Goals and Objectives of the study}

\section{Goal}

To determine affecting of the knowledge and attitude of the fish stakeholders to quality deterioration of the fish.

\section{Objectives}

To study factors affecting the quality deterioration of fish

To study knowledge, attitude and the behaviors of the fish stakeholders

To study quality deterioration of the fish during harvesting, handling, post harvesting, transporting and storage

* To study how to control the factors to minimize quality of fish

* To study how to improve the knowledge, attitude and the behaviors of the fish stakeholders 


\section{LITERATURE REVIEW}

\subsection{Marine Fish}

Salt water fish separates them in to two groups depending on the depth of water in which they are found, which is correlated with great differences in the fish's fat content Pelegic fish and Demersal fish. (Potter \& Hotchkiss, 1996)

\subsubsection{Pelergic fish}

Fish found in the middle and surface water layers of the sea are called pelagic fish include Herring, Mackerel, Salmon, Tuna, Sardines and Anchorites (Kelawalla, Balaya, Atawalla, Kopparawa, Bolla, Kumbalawa). This group includes many of the fatty fish which is some instances have muscle containing $20 \%$ fat reserve under skin. They have more red muscle and oily off white appearance flesh.

\subsubsection{Dermersal fish}

Dermersal fish is found at or near the bottom of the sea, ordinarily on the continental shelves and includes whiting, flat fish such as Carangid sp, Rays, Brains, Ocean perch, Shrimp, Oysters, Clams and Crab(Parawa, Galmalu, Kossa, Maduwa). Demersal fish usually have less than $5 \%$ fat and some times less than $1 \%$ fat in the muscle. In this fish fat deposited in liver and have white flesh. (Hall,1990)

\subsection{Composition and Nutrition}

The composition and nutritional properties of the edible muscle of fish of a given species are quite variable, depending on season of the year, degree of maturity, and other factors. The herring, for example, may vary in muscle fat from about $8 \%$ to $20 \%$ with changes in the season and available food supply. The composition of most fish falls in the ranges of about $18-35 \%$ total solids, $14-20 \%$ protein, $0.2-20 \%$ fat, and $1.0-$ $1.8 \%$ ash. (Potter \& Hotchkiss, 1996) 